\title{
Innovative doctorate programs in cybersecurity, engineering, and technology in the USA and UK that can be completed by professionals around the world without relocation
}

\author{
Dr. Darrell Norman Burrell \\ Florida Institute of Technology \\ https://orcid.org/0000-0002-4675-9544 \\ https://www.researchgate.net/profile/ \\ Darrell Burrell2
}

\author{
Dr. Maurice E. Dawson \\ Illinois Technical University \\ https://orcid.org/0000-0003-4609-3444 \\ https://www.researchgate.net/profile/ \\ Maurice Dawson2
}

\author{
Dr. Calvin Nobles \\ Temple University
}

\begin{abstract}
Every year in the U.S., 40,000 jobs for information security analysts go unfilled, and employers are struggling to fill 200,000 other cybersecurity-related roles. Colleges and universities have created certificates, undergraduate and graduate programs to train professionals in these job roles. The challenge of meeting the cybersecurity workforce shortage through degree programs is intensified by the reality of the limited number of cybersecurity and engineering faculty at colleges and universities. This paper explores the essential need to develop more doctorate faculty in technology-related areas. It explains some unique and non-traditional paths to doctoral completion that allow professionals with significant real-world work experience to complete a doctorate without career interruption and relocation from highly respected and established universities in the U.K., USA, and Australia.
\end{abstract}

Index Terms-Doctoral studies, cybersecurity doctorates, faculty development, Engineering doctorate, on-line doctorate.

\section{INTRODUCTION}

A CCORDING to Newman (2016), the cybersecurity threat landscape is continually evolving as malicious cyber actors pursue new vectors to target and capitalize on newly discovered or known vulnerabilities. In 2017 a hacking group known as the Shadow Brokers, claiming to have breached the NSA-linked operation known as the Equation Group. The Shadow Brokers provided samples of the stolen data and attempted to auction off other stolen data (Newman, 2017).

The global cybersecurity workforce will have more than 1.5 million unfilled positions by 2020 (Van- Zadelhoff, 2016). Every year in the U.S., 40,000 jobs for information security analysts go unfilled, and employers are struggling to fill 200,000 other cyber-security related roles (Kauflin, 2017). Threats of cyber-attacks have spurred global interest in protecting digital property from external intrusions. The identified risks to American private and public entities were part of an ongoing scenario that emphasized secure, internal, cyber information (Pierce, 2016; Stevenson, 2017). This importance came about because many in the business market had echoed the need for a skilled workforce within cybersecurity, and numerous efforts were made to address those concerns (Pierce, 2016; Stevenson, 2017).

\section{THE REVIEW OF THE Literature}

The onslaught of cyber-attacks enhanced the need to fill positions focused on preventing data breaches (Pierce, 2016; Stevenson, 2017).

Besides, the shortage of skilled personnel provided a new dynamic to finding qualified workers that understood the complexities of cybersecurity, contributing significantly to the company's overall needs (Pierce, 2016; Stevenson, 2017).

Technologies have also led to significant changes in how our society communicates and even completes a college degree (Rahim, Burrell, Duncan, \& Finch, 2020). Emerging technologies have allowed the pursuit of academic scholarship to take on new forms and new multimodal ways (Rahim, Burrell, Duncan, \& Finch, 2020).

More importantly, they can provide students with multimodal ways to consume information and ultimately promote learning (Rahim, Burrell, Duncan, \& Finch, 2020). That is also true for graduate education, specifically doctoral capstone projects. In many academic fields of study, newer forms of media have yet to be used as a tool for expressing and communicating academic content. Educational institutions still retain the dissertation's traditional form as the demonstrative tool of academic knowledge and doctoral experience.

Fell, Flint \& Haines (2011) have added practice-based rather than discipline dependent research. They also highlighted that professional doctorates are embraced by working people with vast professional experience. Simultaneously, they are customarily undertaken within the student's work environment to produce practical knowledge for professional practice and the profession, leading eventually to professional and organizational change). Fell, Flint \& Haines 2011). The Council of Graduate Schools developed a publication titled The role and nature of the doctoral dissertation: a policy statement contends that "dissertation research should provide students with handson, directed experience in the primary research methods of the discipline, and should prepare students for the types of research/scholarship that will be expected of them after they receive their Ph.D. degree" (Hancock, 1991, p. 3).

The emergence of on-line and non-traditional educational programs has created new innovative solutions for 
addressing workforce development shortages by allowing professionals must work to be still able to pursue education and professional development opportunities (Rahim, Burrell, Duncan, \& Finch, 2020). Universities are creating new degree programs and new approaches to learning that facilitate the innovative expression of academic scholarship (Rahim, Burrell, Duncan, \& Finch, 2020).

These innovations have also included changes and new approaches to doctoral education. Perry \& Imig (2008) outline, "as a result of these conversations, new forms of the capstone project are emerging. For example, the University of Southern California program has introduced thematic dissertations, wherein students conduct individual investigations of field-based problems as part of a group organized around a set of related problems. The University of Houston has put together a candidacy paper task force, which considers capstone models such as a needs analysis for educational institutions, the development of institutional-change plans, and a critical analysis of a district program. Both the University of MissouriColumbia and the University of Florida are considering the role that solving "real-world" problems might play in a capstone piece. As a result of the focus on problems of practice, some institutions have suggested that the dissertation committee should include professional as well as academic members."

\section{The DeVelopment Of Non-Traditional DOCTORAL PROGRAMS}

Several accredited U.S. universities have successfully developed non-traditional doctoral programs that offer limited face to face teaching residencies and on-line learning. These programs allow students from all over the world to complete a doctoral degree in Information Technology, Engineering, and Cybersecurity while working full time and not moving or relocating to complete their degrees. These are all brick and mortar universities that are leveraging their campus resources to engage professionals with significant work experience in the field, which could become effective faculty members in the future with a doctorate degree. These programs have several similar characteristics, like either on-line or limited residency offerings. These programs have coursework combined with dissertation research. These schools include:

1. The George Washington University in Ashburn VA, USA offers an on-line Doctor of Engineering that can be finished remotely in Cybersecurity and Technology Management

2. Old Dominion University in Norfolk, VA, U.S. offers an on-line Ph.D. in engineering management and systems engineering.

3. Dakota State University in Madison, South Dakota, USA, has an on-line Ph.D. in Information Security.

4. The University of the Cumberlands in Williamsburg, KY, USA, has an on-line Ph.D. in Information
Technology with options to study Blockchain Technology at the graduate level on-line.

5. Mississippi State University in Starkville, MS, USA has an on-line Ph.D. in Systems and Industrial Engineering.

\section{U.S. Research ONLY Ph.D. Program}

Usually, the U.S. approach to doctoral study includes academic coursework and then dissertation research. Still, one university in the U.S., Capitol Technology University, in Laurel, Maryland, USA, has a doctoral approach like many European Universities where students engage in their independent research. This program also allows students who have completed doctoral credits at other universities but failed to achieve their doctorate to transfer their credits and complete their doctorate in an accelerated format. They offer Ph.D. programs in Artificial Intelligence, Emergency and Protective Services, Human Factors, Unmanned Systems Applications, and Technology.

\section{Ph.D. By Published Research OR Ph.D. By PUBLICATION}

The Ph.D. by Published Research or Ph.D. by Published Works emerged as an option in 1966 at Cambridge University in the U.K. and has grown to become a viable path for doctoral degree completion in the U.K. and Australia (Peacock, 2017). The Ph.D. by published works was initially conceived to allow practitioners such as creative writers, artists, and accomplished executive to obtain an earned doctorate that would afford them the ability to take their knowledge, experiences, and accomplishments along with a doctorate degree in the university classroom (Peacock, 2017).

The Ph.D. by published works program works by the students submitting a collection of prior peer-reviewed published research and works all from the matching field for examination (Peacock, 2017). The portfolio submission can include peer-reviewed full paper conference proceedings, peer-reviewed academic articles, and peer-reviewed book chapters. The submission of published works is critical content analysis as an evaluated equivalent to fulfilling requirements for a doctoral degree (Peacock, 2017). The critical content analysis explains the relevance, impact, and unifying significance of the publications in the academic field (Peacock, 2017). Universities offering these programs include:

Middlesex University in the U.K. offers a Doctor of Professional Studies by published works.

London Metropolitan University in the U.K. offers a Ph.D. by Published Works.

These universities offer flexible doctoral programs that are a perfect fit for working professionals of those that want to be able to work full time while they pursue a doctorate. These programs also offer organizations new options support high potential employees with professional 
development funding support for these employees to pursue doctoral level professional development. Each program is geared towards working professionals and executives in the Cybersecurity, Engineering, and fields to bring their expertise to universities that are challenged to meet new workforce demands in Technology, Engineering, and Cybersecurity.

\section{REFERENCES}

[1] Andre, P. (2016). A phenomenological study of frontline hiring professionals that recruit in a cybersecurity world (Order No. 10250990). Available from ProQuest Dissertations \& Theses Global. (1868414289).

[2] Burrell, D., Nobles, C. (2018). Recommendations to Develop and Hire More Highly Qualified Women and Minority Cybersecurity Professionals. Proceedings of ICCWS 2018 13th International Conference on Cyber Warfare and Security. Academic Conferences International Limited.

[3] Cappelli, P. (2008). Talent management for the twenty-first century. Harvard business review, 86(3), 74.

[4] Cappelli, P., \& Novelli, W. D. (2010). Managing the Older Worker: How to Prepare for the New Organizational Order. Harvard Business Press.

[5] Clancy, M. (2012). Improving faculty professional development in higher education high-tech programs: An action science research study of self-directed professional development (Order No. 3542028). Available from ProQuest Dissertations \& Theses Global.

[6] Curricula, C. (2001). Computer Science. IEEE CS, ACM Joint Task Force on Computing Curricula.

[7] Delia, C. (2015). Exploring the social and organizational factors of the shortage of women in information technology: A multiple case study (Order No. 3732277). Available from ProQuest Dissertations \& Theses Global. (1746623174).

[8] Fell, A.F., Flint, K.J., \& Haines, I. (2011). Professional doctorates in the UK 2011. Lichfield, Staffordshire: UK Council for Graduate Education.

[9] Fenge, L.A. (2009). Professional doctorates: A better route for researching professionals? Social Work Education, 28(2), 165-176.

[10] Fink, D. (2006). The professional doctorate: its relativity to the $\mathrm{PhD}$ and relevance for the knowledge economy. International Journal of Doctoral Studies, 1, 35-44.

[11] Force, J. T. (2001). Computing curricula 2001: Computer science. Retrieved https://www.acm.org/education/curric_vols/cc2001.pdf

[12] Fuller, C. R. (2016). Shortening the skills gap: An exploratory study of cybersecurity professional experience (Order No. 10250901). Available from ProQuest Dissertations \& Theses Global. (1868417653).

[13] Hancock, K. L. (1991). The role and nature of the doctoral dissertation: a policy statement. Washington, DC: Council of Graduate Schools.

[14] Herling, L. (2011). Hispanic women overcoming deterrents to computer science: A phenomenological study (Order No. 3505844). Available from ProQuest Dissertations \& Theses Global. (1013441827).

[15] Kauflin, J. (2017, March 16) The Fast-Growing Job with A Huge Skills Gap: Cyber Security. Forbes
[16] Li, J., \& Daugherty, L. (2015). Training cyber warriors: What can be learned from defense language training? Santa Monica, CA: RAND National Defense Research Institute.

[17] McClurg, J. D. (2015). Cybersecurity in higher education: Oversight and due diligence (Order No. 10291072). Available from ProQuest Dissertations \& Theses Global. (1846958719). Retrieved from https://search-proquestcom.contentproxy.phoenix.edu/docview/1846958719? accountid $=35812$

[18] Morgan, S. (2016, May 13). Top 5 industries at risk of cyberattacks. Forbes.com. Retrieved on February 17, 2018, from https://www.forbes.com/sites/stevemorgan/2016/05/13/list-of-the5-most-cyber-attacked-industries/\#1 edfc 762715e

[19] Newman, L. (2017, July 1) The biggest cybersecurity disasters of 2017 so far. WIRED.

[20] Palmer, R. T., Maramba, D. C., \& Gasman, M. (Eds.). (2013). Fostering Success of Ethnic and Racial Minorities in STEM: The Role of Minority Serving Institutions. New York, NY: Routledge. $264 \mathrm{pp}$.

[21] Pierce, A. O. (2016). Exploring the cybersecurity hiring gap (Order No. 10250186). Available from ProQuest Dissertations \& Theses Global. (1848667353).

[22] Perry, J. A., \& Imig, D. G. (2008). A Stewardship of Practice in Education. Change Magazine, (November/December).

[23] President's Council of Advisors on Science and Technology. (2012). Report to the president: Engage to excel: Producing one million additional college graduates with degrees in science, technology, engineering, and mathematics. Retrieved from http://www.whitehouse.gov/sites/default/files/microsites/ostp/pcast -engageto-excel-final 2-25-12.pdf

[24] Rahim, E., Burrell, D. N., Duncan, T., \& Finch, A. (2020). Best Practices and Emerging Trends for Knowledge-Based Organizations and Academic Institutions around ELearning. International Journal of Smart Education and Urban Society (IJSEUS), 11(2), 16-27. doi:10.4018/IJSEUS.2020040102

[25] Strayhorn, T. L. (2010). Undergraduate research participation and STEM graduate degree aspirations among students of color. New Directions for Institutional Research, 2010 (148).

[26] Sweem, S. L. (2009). Leveraging employee engagement through a talent management strategy: Optimizing human capital through human resources and organization development strategy in a field study (Order No. 3349408). Available from ProQuest Dissertations \& Theses Global. (305162419).

[27] Shackelford, R., Lunt, B., McGettrick, A., Sloan, R., Topi, H., Davies, G., Lunt, B. (2006). Computing curricula 2005: The overview report. [Association for Computing Machinery] ACM [Special Interest Group on Computer Science Education] SIGCSE, 38(1), 456-457.

[28] Stevenson, G. V. (2017). Cybersecurity implications for industry, academia, and parents: A qualitative case study in NSF STEM education (Order No. 10624075). Available from ProQuest Dissertations \& Theses Global. (1958945736).

[29] Tucker, A. B., Aiken, R. M., Barker, K., Bruce, K. B., \& Cain, J. T. (1991). Computing curricula 1991: Report of the ACM/IEEECS Joint Curriculum Task Force. New York, NY: Association for Computing Machinery Press/IEEE Press.

[30] Van-Zadelhoff, Marc (2016, September). The Biggest Cybersecurity Threats Are Inside Your Company. Harvard Business Review.

[31] Wilson, M. D. (2015). A qualitative case study of the talent management process across project-oriented companies within the intellect industry (Order No. 3687744). Available from ProQuest Dissertations \& Theses Global. (1669973498). 